\title{
Penggunaan Antibiotik Profilaksis Pada Pembedahan Terbuka Batu Saluran Kemih Di RSUD Arifin Ahmad Provinsi Riau
}

\author{
Dimas Pramita Nugraha $^{1 *}$, Dina fauzia ${ }^{1}$, M.Yulis Hamidy ${ }^{1}$, M.Irvan Noorrahman ${ }^{2}$
}

\begin{abstract}
Open surgery urinary tract stones are classified as clean-contaminated surgerywheresurgical prophylactic antibiotics are recommended.The purpose of this study was to determine the pattern and correct use of surgical prophylactic antibiotic in patients undergoing open surgery urinary tract stones in Arifin Ahmad Hospital.This research is a descriptive study using secondary data from medical records of patients who underwent open surgery urinary tract stones, with a total sample amounted to 82 people. The precision of the use of antibiotics assessed based PermenkesGuidelines Use of Antibiotics. The results showed the use of prophylactic antibiotics for urinary tract surgery have not been precisely classified according to the indication the use of antibiotics andthe timing of antibiotics.Even though the duration antibiotics, dosage, and route of administration of prophylactic antibiotics are appropriate under the guidelines. The use of prophylactic antibiotics for open surgery urinary tract stones need improvement.
\end{abstract}

Key words: Surgery, urinary tract stones, prophylactic antibiotics

Antibiotik profilaksis merupakan bagian dari pencegahan infeksi. Antibiotik yang diberikan pada pasien bedah bertujuan untuk mengurangi jumlah koloni bakteri, mengurangi jumlah inokulum kontaminasi sehingga menurunkan risiko infeksi atau sebagai terapi apabila sudah dalam keadaan infeksi sebelumnya. Pada tindakan profilaksis, antibiotic diberikan sebelum terdapat tanda infeksi. Untuk mencapai optimasi pemberian antibiotic profilaksis, terdapat beberapa hal yang menjadi pertimbangan pada pemberiannya, yaitu: apakah terapi profilaksis diperlukan, apa jenis antibiotik yang akan diberikan, apakah antibiotic diberikan secara oral atau intravena, kapan memulai terapi dan berapa lama diberikan. ${ }^{1,2,3}$

Infeksi daerah pembedahan merupakan salah satu masalah dalam penanganan pasca bedah. Insidensnya menduduki peringkat kedua sebagai penyebab infeksi nosokomial, dan berdampak pada peningkatan morbiditas dan mortalitas, dan biaya pengobatan. Insidensnya bervariasi antara 2-20\%

\footnotetext{
* Penulis untuk korespondensi : dr_dimas_nugraha @yahoo.com

KJF Farmakologi Fakultas Kedokteran universitas Riau

2 Fakultas Kedokteran Universitas Riau
}

dari intervensi dan bergantung pada jenis pembedahannya. ${ }^{3,4}$ Di Amerika Serikat insidensnya sebesar 2,6\% meskipun telah diterapkan standar sterilisasi dan desinfeksi, penyaringan udara di kamar pembedahan dan pemberian antibiotik profilaksis. Hal ini berkaitan dengan meningkatnya populasi dengan risiko tinggi seperti usia lanjut dan populasi dengan penyakit penyerta seperti diabetes melitus, gagal ginjal kronik dan lain-lain. ${ }^{4,5}$

Salah satu pembedahan yang paling sering terjadi dibidang urologi adalah bedah terbuka batu saluran kemih. Rata-rata di seluruh dunia angka kejadian penyakit batu saluran kemih (BSK) adalah 1-12\%. Amerika Serikat penduduknya 5-10 \% menderita penyakit ini. ${ }^{6}$ Di RSUD Arifin Achmad Provinsi Riau angka kejadian batu saluran kemih tahun 2002-2006 adalah 81,7\% pada laki-laki dan $18,3 \%$ pada perempuan.

Pembedahan terbuka batu saluran kemih merupakan salah satu tindakan pembedahan yang tergolong pembedahan bersih-kontaminasi (cleancontaminated), dimana pemberian antibiotik profilaksis bedah sangat direkomendasikan. ${ }^{6}$ Pemberian antibiotic profilaksis bedah pada setiap pembedahan bersih-kontaminasi terbukti efektif dalam menurunkan angka kejadian infeksi luka 
pembedahan. Efektifitas antibiotic profilaksis bedah sangat tergantung pada konsentrasi antibiotik di daerah insisi, dimana setidaknya mencapai konsentrasi hambat minimal. Oleh karena itu, pilihan antibiotik, dosis antibiotik, waktu dan lama pemberian, serta cara pemberian antibiotic menjadi factor penentu keberhasilan tindakan profilaksis tersebut. $^{7}$

Berdasarkan hal diatas sangat menarik mengetahui ketepatan penggunaan antibiotic profilaksis bedah pada pasien yang menjalani pembedahan batu saluran kemih di RSUD Arifin Ahmad Provinsi Riau. Diharapkan hasil penelitian ini nantinya dapat memberikan masukan berupa perbaikan pelayanan medis khusus pelayanan bedah melalui penyusunan kebijakan penggunaan antibiotik di RSUD Arifin Ahmad Provinsi Riau.

\section{METODE}

Penelitian ini merupakan studi deskriptif menggunakan data sekunder berupa rekam medik pasien untuk menggambarkan pola dan ketepatan penggunaan antibiotic profilaksis bedah pada pasien. Data dikumpulkan dari rekam medic pasien yang menjalani pembedahan batu saluran kemih di RSUD Arifin Ahmad Provinsi Riau Periode 1 Januari 2014 - 31 Desember 2014.
Data rekam medic pasien yang dicatat meliputi karakteristik/data demografi (inisial nama pasien, usia/tanggal lahir, nomor rekam medik, jenis kelamin, berat badan, tanggal mulai rawat inap), deskripsi tindakan pembedahan batu saluran kemih (jam mulai pembedahan, lama pembedahan, jumlah perdarahan intraoperatif), penggunaan antibiotic profilaksis bedah (jenis antibiotik, dosis, jalur pemberian, jam pemberian, penambahan antibiotic profilaksis intraoperatif, lama pemberian). Ketepatan penggunaan antibiotik dinilai berdasarkan Permenkes penggunaan antibiotik.

\section{HASIL}

Berdasarkan data rekam medik setelah diseleksi berdasarkan kriteria inklusi, maka diperoleh subjek penelitian sebanyak 82 orang pasien. Distribusi karakteristik subjek penelitian menunjukkan bahwa sebagian besar subjek penelitian merupakan pasien laki-laki $(69,5 \%)$ dan berusia 19 sampai dengan 59 tahun $(80,5 \%)$. Pembedahan semuanya dilakukan secara elektif (100\%), dengan jenis pembedahan yang paling banyak adalah ureterolitotomi $(35,4 \%)$. Anestesi yang terbanyak digunakan adalah anestesi umum $(70,7 \%)$ (Tabel 1).

Tabel 1.Distribusi Karakteristik Subjek Penelitian

\begin{tabular}{lcc}
\hline \multicolumn{1}{c}{ Karakteristik } & Jumlah pasien & Persentase \\
\hline Jeniskelamin & 57 & 69,5 \\
Laki-laki & 25 & 30,5 \\
Perempuan & & \\
Kelompok usia & 1 & 1,2 \\
$<19$ Tahun & 66 & 80,5 \\
19-59 Tahun & 15 & 18,3 \\
>60 Tahun & & \\
Sifatpembedahan & 0 & 0 \\
Emergensi/cito & 82 & 100 \\
Elektif & & \\
Jenispembedahan & 6 & 7,3 \\
Nephrolitotomi & 20 & 24,4 \\
Pyelolitotomi & 29 & 35,4 \\
Ureterolitotomi & 18 & 21,9 \\
Vesicolitotomi (sectioalta) & 8 & 9,8 \\
Nefrectomi & 1 & 1,2 \\
Pyelolitotomi +Ureterolitomi & & \\
Teknikanestesi & 58 & 70,7 \\
AnestesiUmum & 22 & 26,9 \\
Anestesi Spinal & 2 & 2,4 \\
Anestesi Epidural & & \\
\hline
\end{tabular}


Pyelolitotomi Ureterolitotomi Vesicolitotomi (sectioalta) Nefrectomi Pyelolitotomi + Ureterolitomi Teknik anestesi Anestesi Umum Anestesi Spinal Anestesi Epidural 2029188158222 $24,435,421,99,81,270,726,92,4$

Frekuensi penggunaan antibiotik profilaksis pada pasien bedah terbuka batu saluran kemih ditunjukkan pada Tabel2. Penelitian ini menunjukkan bahwa pasien bedah terbuka batu saluran kemih yang menggunakan profilaksis antibiotic sebanyak 42 orang $(51,2 \%)$, sebanding dengan pasien yang tidak menggunakan antibiotic yaitu 40 orang $(48,8 \%)$.

Tabel 2.Penggunaan Antibiotik Profilaksis Bedah Batu Saluran Kemih

\begin{tabular}{lcc}
\hline Penggunaan Profilaksis Antibiotik & Frekuensi & Persentase (\%) \\
\hline -Menggunakan Profilaksis & 42 & 51,2 \\
-Tidak menggunakan profilaksis & 40 & 48,8 \\
\hline
\end{tabular}

Gambaran golongan antibiotik profilaksis yang digunakan pada pembedahan di tunjukkan oleh tabel 3. Antibiotik yang digunakan sebagai profilaksis dalam pembedahan batu saluran kemih pada penelitian ini semuanya menggunakan golongan sefalosporin yaitu ceftriaxone.

Tabel 3. Golongan Antibiotik Profilaksis yang Digunakan

\begin{tabular}{|c|c|c|}
\hline Golongan Antibiotik & Frekuensi & Persentase (\%) \\
\hline - Sefalosporin & 42 & 100 \\
\hline - Golongan Lain & 0 & 0 \\
\hline
\end{tabular}

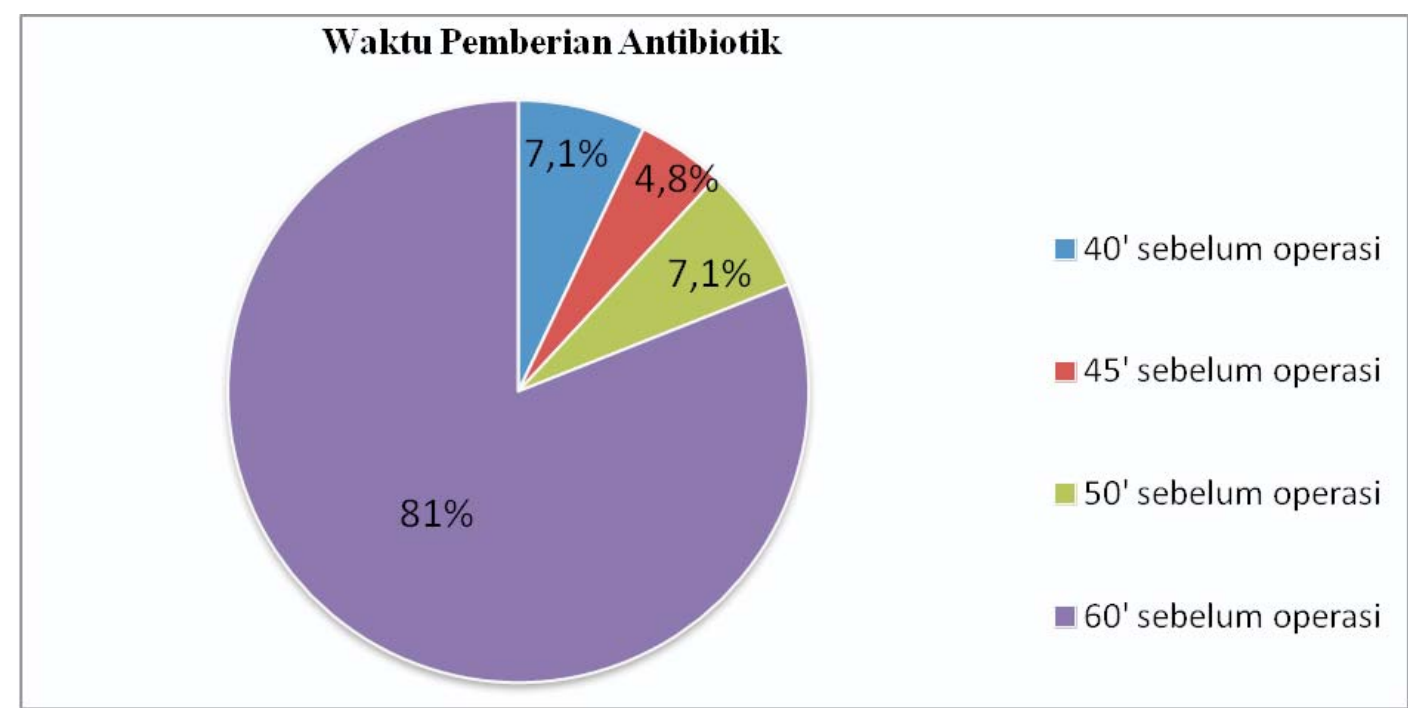

Gambar 1. Waktu Pemberian Antibiotik Profilaksis

Waktu pemberian antibiotik profilaksis ditunjukkan pada gambar 1.Hasil menunjukkan bahwa waktu pemberian antibiotik yang terbanyak pada penelitian ini adalah 60 menit ( $1 \mathrm{jam}$ ) sebelum pembedahan dilakukan (81\%), dan paling sedikit 40 menit sebelum operasi.
Gambaran dosis pemberian antibiotik profilaksis di deskripsikan pada tabel 4.Dosis antibiotik sefalosporin yang diberikan kepada pasien yang mendapatkan profilaksis (42 orang) semuanya sebesar 1 gram. 
Tabel 4. Dosis Pemberian Sefalosporin

\begin{tabular}{lcc}
\hline Dosis Sefalosporin & Frekuensi $(\mathrm{N})$ & Persentase (\%) \\
\hline 1 gram & 42 & 100 \\
Dosis lain & 0 & 0 \\
\hline
\end{tabular}

Lama pemberian antibiotik profilaksis bedah saluran kemih pada penelitian ini semuanya $<24$ jam (tabel 5). Rute pemberian antibiotik profilaksis bedah batu saluran kemih semuanya (100\%) melalui rute intravena (Tabel 6).

Tabel 5. Lama Pemberian Antibiotik Profilaksis

\begin{tabular}{ccc}
\hline Lama Pemberian Antibiotik & Frekuensi & Persentase (\%) \\
\hline$<24 \mathrm{Jam}$ & 42 & 100 \\
$>24 \mathrm{jam}$ & 0 & 0 \\
\hline
\end{tabular}

Tabel 6. Rute Pemberian Antibiotik Profilaksis

\begin{tabular}{lcc}
\hline Rute Pemberian Antibiotik & Frekuensi & Persentase (\%) \\
\hline Intravena & 42 & 100 \\
Peroral & 0 & 0 \\
\hline
\end{tabular}

\section{PEMBAHASAN}

\section{Penggunaan Antibiotik Profilaksis Pada Pembedahan Batu Saluran kemih}

Berdasarkan hasil penelitian diketahui bahwa persentase pasien pembedahan terbuka batu saluran kemih yang diberikan profilaksis antibiotik sebesar $51,2 \%$ sebanding dengan yang tidak mendapatkan profilaksis antibiotik 48,8\%.Hasil ini kurang menggembirakan, karena sistematik review terhadap pemberian antibiotik profilaksis pada pembedahan urologi, merekomendasikan bahwa pembedahan terbuka saluran kemih dengan kategori clean contaminated memiliki indikasi untuk diberikan antibiotik profilaksis sebelum pembedahan. Pemberian antibiotik profilaksis ditujukan umtuk meminimalkan komplikasi infeksiyang dihasilkan dari intervensi diagnostic dan terapeutik..$^{8,9,12}$

\section{Ketepatan Penggunaan Antibiotik Profilaksis Bedah Berdasarkan Indikasi Pemberian Antibiotik}

Hasil penelitian menunjukkan bahwa hanya $51,2 \%$ pasien yang mendapatkan antibiotik profilaksis. Artinya, penggunaan antibiotik profilaksis bedah dikategorikan tepat berdasarkan indikasi pemberian sebesar $51,2 \%$ dan sisanya $48,8 \%$ adalah tidak tepat.
Hasil ini menunjukkan masih cukup banyak sejawat dokter bedah yang belum begitu memperhatikan aspek preventif dan patient safety dalam pembedahan, apalagi semua pembedahan dalam penelitian ini tergolong pembedahan bersih terkontaminasi (clean-contaminated), dan berdasarkan Permenkes 2406 tahun 2011 tentang pedoman umum penggunaan antibiotik profilaksis sangat direkomendasikan. ${ }^{11-13}$

\section{Ketepatan Penggunaan Antibiotik Profilaksis Bedah Berdasarkan Pemilihan Antibiotik}

Berdasarkan pemilihan antibiotik, dari 42 pasien $(100 \%)$ yang diberikan ceftriaxone sebagai antibiotik profilaksis bedah sebelum menjalani pembedahan batu saluran kemih termasuk kategori kurang tepat, oleh karena menurut permenkes pedoman penggunaan antibiotik 2011 yang dianjurkan digunakan untuk profilaksis adalah golongan sefalosporin generasi pertama atau kedua. Sedangkan generasi ketiga dan keempat kurang dianjurkan. ${ }^{13}$

Antibiotik profilaksis yang digunakan pada studi ini semuanya adalah golongan sefalosporin generasi ketiga yaitu ceftriaxon. Penggunaan antibiotik ceftriaxson kemungkinan dikarenakan antibiotik tersebut mempunyai spektrum yang luas 
dan memiliki waktu paruh yang lebih panjang dibandingkan sefalosporin yang lain, sehingga cukup diberikan satu kali sehari. ${ }^{8,9}$

\section{Ketepatan Penggunaan Antibiotik Profilaksis Bedah Batu saluran Kemih Berdasarkan Waktu, Dosis, Lamadan Rute PemberianAntibiotik}

Waktu terbanyak pemberian profilaksis adalah 1 jam sebelum pembedahan. Ketepatan waktu pemberian antibiotik profilaksis belum ada yang mengikuti rekomendasi Permenkes 2011 yaitu d"30 menit sebelum pembedahan. Walaupun menurut Chen dkk (2007) dan Fonseca (2006) pemberian antibiotik profilaksis 1 jam sebelum insisi masih dibenarkan..$^{5,8,13}$

Ketepatan dosis pemberian antibiotik profilaksis bedah pada pasien batu saluran kemih yang diberikan pada penelitian ini sudah tepat mengacu pada guideline yaitu 1 gram. ${ }^{11-13}$

Bila dilihat berdasarkan lama pemberian antibiotik profilaksis bedah, seluruh pasien yang mendapatkan antibiotik (42 orang) mendapat antibiotik profilaksis bedah $<24$ jam dan hal ini dikategorikan tepat. ${ }^{12,13}$ Rute pemberian antibiotik profilaksis bedah seluruhnya (100\%) melalui intravena dan dikategorikan tepat. ${ }^{13}$

Berbagai pedoman antibiotic profilaksis bedah telah dipublikasikan, aspek yang menjadi perhatian dari pedoman tersebut menyangkut indikasi, pilihan antibiotik, dosis optimal, waktu dan lama pemberian, serta cara pemberian. Menurut The Scottish Intercollegiate Guidelines Network (SIGN) guideline on antibiotic prophylaxis in surgery (SIGN 45) tahun 2008, antibiotic profilaksis bedah harus tetap digunakan dengan prinsip bahwa antibiotik yang digunakan tersebut harus didukung oleh bukti keefektifannya, meminimalkan pengaruh antibiotic tersebut terhadap flora bakteri normal pasien, meminimalkan efek samping antibiotik terhadap pasien, dan meminimalkan efek antibiotic terhadap kekebalan tubuh pasien. ${ }^{10,12}$

\section{KESIMPULAN}

Penggunaan antibiotik profilaksis pada bedah terbuka saluran kemih tergolong belum tepat menurut indikasi pemberian antibiotik (48,8\% tidak diberikan antibiotik). Pemilihan antibiotik kurang tepat(100\% menggunakan sefalosporin generasi ke tiga) danwaktu pemberian antibiotik kurang tepat (semua diberikan >30 menit). Sedangkan untuk lama pemberian antibiotik, dosis dan rute pemberian antibiotik profilaksis sudah tepat.

\section{DAFTAR PUSTAKA}

1. Lubelski J, Konings WN, Driessen AJM. Distribution and physiology of ABC-type transporters contributing to multidrug resistance in bacteria. Microbiol Mol Biol Rev. 2007; 71:463-476.

2. Poole K. Mechanism of antimicrobial resistance : oppurtunities for new targeted therapies. Adv Drug Deliv Rev.2005; 57:1443-1445.

3. Murthy R. Implementation of strategies to control antimicrobial resistance. Chest 2001;119:405S-11S.

4. Weinstein RA. Controlling antimicrobial resistance in hospitals: Infection control and use of antibiotics. Emerg InfectDis.2001;7:188-92.

5. Fonseca SNS, Kunzle SRM, Junqueira MJ, Nascimento RT, Ivan de Andrade J, Levin AS. Implementing 1-dose antibiotic prophylaxis for prevention of surgical site infection. Arch Surg. 2006;141:1109-13.

6. Bratzler DW, Houck PM, Richards C, Steele L, Dellinger EP, Fry DE, et al. Use of antimicrobial prophylaxis for major surgery: baseline results from the national surgical infection prevention project. Arch Surg. 2005;140:174-82.

7. Van Kasteren MEE, Mannien J, Kullberg BJ, de Boer AS, Nagelkerke NJ, Ridderhof M, et al. Quality improvement of surgical prophylaxis in Dutch hospitals: evaluation of a multi-site intervention by time series analysis. J. Antimicrob. Chemother. 2005;56:1094-102.

8. Chen K, Setiawan B, Pohan HT. Penggunaanantibiotikuntukprofilaksispadapembedahan. Dalam: Mansjoer A, Sudoyo AW, Alwi I, Rinaldi 
I, Harimurti K, Laksmi PW, dkk. Kedokteranperioperatif: evaluasidantatalaksana di bidangilmupenyakitdalam. Jakarta: Internal Publishing, 2007, hal 60-72.

9. Rudilla MC, Rodríguez JPD, Santana AR, Molist MG, Gómez MAO, Conde JAM, et al. Perioperative pharmacological treatment recommendations. CIR ESP. 2009;86:130-8.

10.Scottish Intercollegiate Guidelines Network. Antibiotic prophilaxis in surgery; A national clinical guideline, 2008.
11. Van der Meer JMW, Van Kasteren M. Improving prescribing in surgical prophylaxis. In: Gould IM, Van der Meer JWM, editors. Antibiotic policies: theory and practice. New York: Kluwer academic Publishers, 2005.p. 185-95.

12.Bootsma AMJ, Laguna PMP, Geerlings SE, Gooseens A, Antibiotiv Prophylaxis in Urologic Procedures: A Systematic Review. EurUrol.2008.p. 1270-1286.

13.Permenkes Pedoman Umum Penggunaan Antibiotik. Kementerian kesehatan Republik Indonesia. 2011. 